Sanja Bungin ${ }^{1}$

Marija Reljić ${ }^{2}$

Bojana Ivković ${ }^{3}$
JEL: C01, E4, E31

DOI: 10.5937/industrija43-9076

UDC: $338.23: 336.74(497.11)$

339.743

Original Scientific Paper

\title{
Estimation of Transmission Mechanism of Monetary Policy in Serbia ${ }^{4}$
}

Article history:

Received: 30 April 2015

Sent for revision: 2 June 2015

Received in revised form: 17 August 2015

Accepted: 1 September 2015

Available online: 15 October 2015

Abstract: Transmission mechanism of monetary policy recently has been subject to several studies in Serbia. The so called "black box" of monetary policy is investigated with aim to identify the effects of transmission channel in environment where exchange rate has a dominant role in central bank operations. Therefore, it is a challenge to approach this problem in inflation targeting regime where key interest rate is expected to prevail as a main policy instrument. The study employs unrestricted Vector Autoregression model for estimating significance of exchange rate and interest rate channel. As expected, exchange rate has far more stronger influence on inflation, even though there are some signs of interest rate channel existence. Introducing Euribor as endogenous variables in VAR system displayed important impact on real variables.

Keywords: monetary policy, inflation targeting, exchange rate, interest rate, inflation, Serbia

\section{Ocena transmisionog mehanizma monetarne politike u Srbiji}

Apstrakt: Transmisioni mehanizam monetarne politike je u skorije vreme bio predmet nekoliko studija u Srbiji.Tzv. "crna kutija" monetarne politike istraživana je sa ciljem da se uoče efekti transmisionog mehanizma u okruženju sa dominantnom ulogom deviznog kursa kao instrumenta centralne

\footnotetext{
${ }^{1}$ sanja.bungin@ecinst.org.rs

2 Economics Institute, Belgrade

${ }^{3}$ Economics Institute, Belgrade

${ }^{4}$ This paper is a part of research projects number 179001 financed by the Ministry of Science and Technological Development of the Republic of Serbia.
} 
banke. Zbog toga, i sam je izazov suočiti se sa ovim problemom kada se u režimu ciljanja inflacije očekuje veća uloga referentne kamatne stope kao glavnog instrumenta monenetarne politike. $U$ studiji je primenjen nerestrikovani model vektorske autoregresije kako bi se ispitao značaj kanala deviznog kursa i kanala kamatne stope. Kao što se moglo i očekivati, devizni kurs ima daleko jači uticaj na inflaciju nego što to ima referentna kamatna stopa, iako ima naznaka o postojanju kamatnog kanala. Uvođenje Euribor kamatne stope kao endogene varijable $u$ VAR sistem dolazi se do zaključka da strana kamatna stopa ima značajan uticaj na kretanje realnih varijabli.

Ključne reči: monetarna politika, ciljanje inflacije, devizni kurs, kamatna stopa, inflacija, Srbija

\section{Introduction}

As in the case of most countries of Eastern Europe who successfully passed the transition, the main goal of monetary policy in Serbia after the democratic changes was combating high and volatile inflation. During that period, the new government faced serious structural economic problems and macroeconomic imbalances. National bank of Serbia used exchange rate as a main monetary tool. This instrument was very successful nominal anchor in disinflation process, however, it created unfavorable situation in balance of payments. Exchange rate appreciation had negative influence on current account and caused high capital inflows. The resulting negative current account balance triggered rising import dependence of Serbian economy, which strengthened the role of exchange rate. Besides, high capital inflows and credit expansion had led to increasing inflation in the case when exchange rate couldn't serve as a single instrument to constrain inflation. For monetary authorities it was clear that current monetary policy is limited when it comes to macroeconomic stability. Introducing new framework of monetary policy, National Bank of Serbia based its policy on principles of inflation targeting, where the main instrument is key interest rate.

One of the first studies, which tried to estimate transmission process in Serbia, is the paper by Vilaret and Palic (2006), where authors investigated exchange rate pass through using ADL and recursive VAR. Their analysis find the evidence of exchange rate pass through, but incomplete and below one. Dragutinovic (2008) also finds evidence of incomplete exchange rate pass through, using the same methodology. The effect of exchange rate is asymmetric, where retail prices react differently during appreciation and depreciation. The transmission effect is higher in case of depreciation than during appreciation. Additionally, Tasic (2008) also investigate exchange rate pass through finding short and long term coefficients below one. Aleksic at al. 
(2008) investigates interest rate channel taking into consideration high level of eurisation in Serbia, using SURE method as empirical tool. According to results, interest rate channel is significant only when eurisation is under control. Josifidis, Allegret \& Beker-Pucar (2009) estimate exchange rate and interest rate pass through to consumer prices, using VAR/VEC econometric tool for Poland, Czech Republic, Slovakia and Serbia. Exchange rate channel is present in Serbia, while the interest rate is weak. Kujundzic and Otasevic (2012) investigate credit channel in euroised economy. Their findings indicate that the growth of domestic currency bank loans is responsive to the domestic and foreign reference rate. On the other hand, authors find weak evidence of the existence of a bank lending channel through foreign currency loans. There are also studies of transmission mechanism for new European Union members who successfully passed transition process. For Czech Republic, Franta at al. (2014) use Bayesian vector autoregression (TVP BVAR) model with stochastic volatility to estimate the evolution of the monetary policy transmission mechanism. Study reports increasing responsiveness of output and prices to monetary policy shocks until the global financial crisis. During crisis time, the responsiveness of output and prices to monetary shocks did not increase, but remained largely constant at the pre-crisis level. BabeckaKucharcukova (2009) finds that speed of the exchange rate shock transmission to all prices is quite high, but low during the period of inflation targeting. There is also evidence that tradable goods react much more to an exchange rate shock than do non-tradable goods, in line with the theoretical foundations. Besides, the magnitude of the exchange rate pass-through decreases from the initial stage of production to final good. Łyziak at al. (2014) investigate structural features of Polish economy and estimate the channels of monetary policy. Evidence shows decreasing influence of exchange rate pass through on consumption prices, due to large degree of a structural nature, reflecting changes in the production process, related to the growing share of production by international firms. In addition, it seems that the inflation response to changes in the central bank interest rates is stronger than the result arising from previous assessments. Authors presume that might stem from faster and slightly stronger influence of demand pressure on prices and from increased degree of forward-lovingness in the economy. Darvas (2013) uses structural time-varying coefficient vector auto regressions to investigate transmission mechanism in Czech Republic, Hungary and Poland in comparison with that in the euro area. Results indicate that response of output to a monetary shock has changed in the euro area as well as in the Czech Republic, Hungary and Poland. Also, "at the last observation of our sample, the fourth quarter of 2011, among the three countries studied, monetary policy was the most powerful in Poland and just slightly less powerful than that in the euro area (though with a different time profile), but the strength of monetary policy was less in Hungary and the Czech Republic." (Darvas, 2013) 
This paper will analyze some of the key structural factors of Serbian market, which are identified as main obstacles for monetary transmission. To estimate the efficiency of transmission mechanism of monetary policy in Serbia via exchange and interest rate channel, econometric tool of vector auto regression is used. The period in the analysis is from January 2007 to December 2014, using monthly data.

\section{Some structural features of financial market and economy}

Structural characteristics of financial sector and economy present crucial conditions for efficient transmission mechanism. There is tight connection between matching the criteria of inflation targeting with these structural features. In this respect, we can indicate the conditions for inflation targeting, such as independence and credibility of central bank, well developed financial market, fiscal discipline. Besides that, it is necessary to consider other characteristics that are crucial for transmission mechanism, such as structure of financial system, eurisation, speculative investors.

One of the main difficulties for unobstructed functioning of transmission mechanism in undeveloped financial market is high level of eurisation. The causes of eurisation in Serbia lay in the previous experience with hyperinflation and high volatile inflation, macroeconomic instability and inherited distrust in dinar (Aleksic at al., 2008). Serbia is not the only country with high eurisation, but it is a leader by this criterion in Eastern Europe. Although the participation of foreign currency loans is quite small, the share of dinar loans indexed in foreign currency is extremely high. On the other hand, foreign currency deposit also has significant share in total deposits. National Bank of Serbia (NBS) has tried with number of measures to reduce the level of eurisation. Dinarisation strategy of financial system, which started in 2010, involves monetary policy measures for contributing to better macroeconomic performance, development of dinar financial instrument, and exchange rate swaps.

Furthermore, the structure of public debt also contributes to high eurisation. Namely, from the beginning of strategy implementation, the foreign currency share in public debt has been approximately two thirds of total debt. Emission of dinar treasury notes partially reduced foreign currency share. Besides the extending of treasury notes maturity as one of the measures, the development of secondary market of government securities also stimulates dinarisation strategy. However, data indicate that turnover on this market is quite insignificant. Also, there is a lack of coordination between monetary and fiscal authorities. At the very beginning of implementation, Ministry of Finance 
started with issues of three, six and twelve month government securities indexed in euros. This was clear signal that NBS has no government support in its actions, and it was reflected on strategy implementation.

In highly eurised economy, there is always a question of successful inflation targeting. Interest rate channel is supposedly inefficient in the case when almost two thirds of loans are indexed in foreign currency. To count on deeurisation, it is necessary to provide macroeconomic stability and lower inflation and exchange rate volatility. To achieve these goals, NBS must have credibility of pursuing its own targets that needs to be supported by Serbian government. Also, it is necessary to develop financial instrument denominated in local currency, especially in the field of government securities, as well as securities of credible financial institutions. Nevertheless, according to Chailloux at al. (2010), it is essential to limit net foreign currency open position, maintain instruments to stimulate dinar saving, limit issues of indexed loans to households with low income and public sector. In that sense, as a part of short term measures, it is necessary to encourage issues of loans in local currency rather than limit the indexed loans.

Money market presents the first phase of monetary transmission, where central bank controls short term segment of financial market. This is processed through determination of key interest that affect yield curve in the segments of financial market relative to investment decisions of private sector, monetary dynamic and price stability. Using the opportunity to monitor interest rates with similar maturity, central bank can influence longer maturities. Functional and liquid money market is fundament which provides central banks to achieve price stability goals. Serbia money market is undeveloped in terms of financial instruments and maturities. There are no instruments characterized for developed markets such as certificate of deposits, commercial paper and interbank repo operations (IMF, 2010). High eurisation of banks' balance sheet position does not motivate banks to actively manage dinar liquidity. Therefore, market activity is mainly focused on two week repo operations.

High turnovers on repo operation are followed by relatively high key interest rate. In this case, financial institutions are motivated go gain risk free profit rather than manage its own liquidity. Therefore, there was evidence of speculative investors' presence that pursued speculative "carry trade". In this case, interest rate losses its main role, while exchange rate strengthens the influence on macroeconomic activities. Also, fiscal discipline is crucial in pursuing efficient monetary policy. Recent reduction of fiscal deficit opens more space for monetary relaxation in terms of lowering key interest rates and required reserves.

On the other hand, secondary money market practically doesn't exist since the turnovers are very low. Concentration on money market also matters in 
terms of transmission channels efficiency. Concentrated market and participants with monopolistic position leads to uncompetitive formation of interest rates and wide spreads, which disturbs credit and interest rate channel even if the first phase of transmission. Although data on this matter are not available, the share of five largest participants in treasury notes and NBS bills can serve as an approximation. Data presented in table below exhibit relatively high money market concentration in Serbia.

Table 1. Money market concentration

\begin{tabular}{|c|c|c|}
\hline & NSB bills market & Treasury notes market \\
\hline 2011. & $60,7 \%$ & $88,75 \%$ \\
\hline 2012. & $56 \%$ & $76,39 \%$ \\
\hline 2014. & $61,27 \%$ & $72,47 \%$ \\
\hline
\end{tabular}

Source: Central Securities Depository and Clearing House

Highly concentrated banking sector also disrupts normal transmission of monetary policy. It is caused by the larger banks which influence the movement of interest rates on loans and deposits. The level of competition has impact on forming prices of banking product. The effect of market concentration on prices in modern literature is defined with to opposite hypothesis (Corvoiser, S., Gropp, R., 2002). "Structure conduct hypothesis" indicates that higher concentration leads to prices that are unfavorable to client. According to hypothesis, only banks with higher market share and better differentiated products can influence interest rates and earn profit. Opposed to that, "efficient structure" hypothesis indicates that concentration uplift overall sector efficiency. The assumption is that when increasing market share of more efficient banks, these banks take over less efficiently. If this is a case, banks can price loans and deposits in more competitive way even on highly concentrated market.

Banking sector in Serbia is not concentrated, according to data related to Herfindahl-Hirschman index (see Reports on banking sector, NBS). Miljkovic at al. (2013) that there is no highly concentrated banking market. However, there are some other issues associated to competition that needs to be examined, such as ownership structure of five larger banks.

Table 2. The share of banks with foreign capital in five largest banks in Serbia on 31.12.2014

\begin{tabular}{|l|c|c|}
\hline & $\begin{array}{c}\text { Share in banking } \\
\text { system assets }\end{array}$ & $\begin{array}{c}\text { Share in banking system } \\
\text { employees }\end{array}$ \\
\hline $\begin{array}{l}\text { Banks with foreign } \\
\text { capital }\end{array}$ & $74,70 \%$ & $67,8 \%$ \\
\hline
\end{tabular}

Source: NBS 
In case of Serbia, we can assume hypothesis that ownership structure determines bank competition. Banks with higher stake of foreign capital have opportunity to finance its activities on international money market through its headquarters abroad. As the price of money abroad is more favorable than on the Serbian market, they are in position to form more competitive interest rates, still having a significant yield. Price of capital on international market is lower than domestic interest rates on deposit, so it can be observed that in balance sheet of foreign banks there is no concept of traditional banking. Besides, NBS data shows that there is only one domestic bank among five largest, which is financed mainly through domestic deposits base. Such structure of banking system implies concentrated market. Banks with foreign ownership are not limited with deposit base, as well as the deposit interest rates when forming the loan prices. Consequently, they are in position to determine lower deposit interest rates which broaden interest rates spread, as well as increases profit.

Figure 1. Interest rate spread on loans and deposits

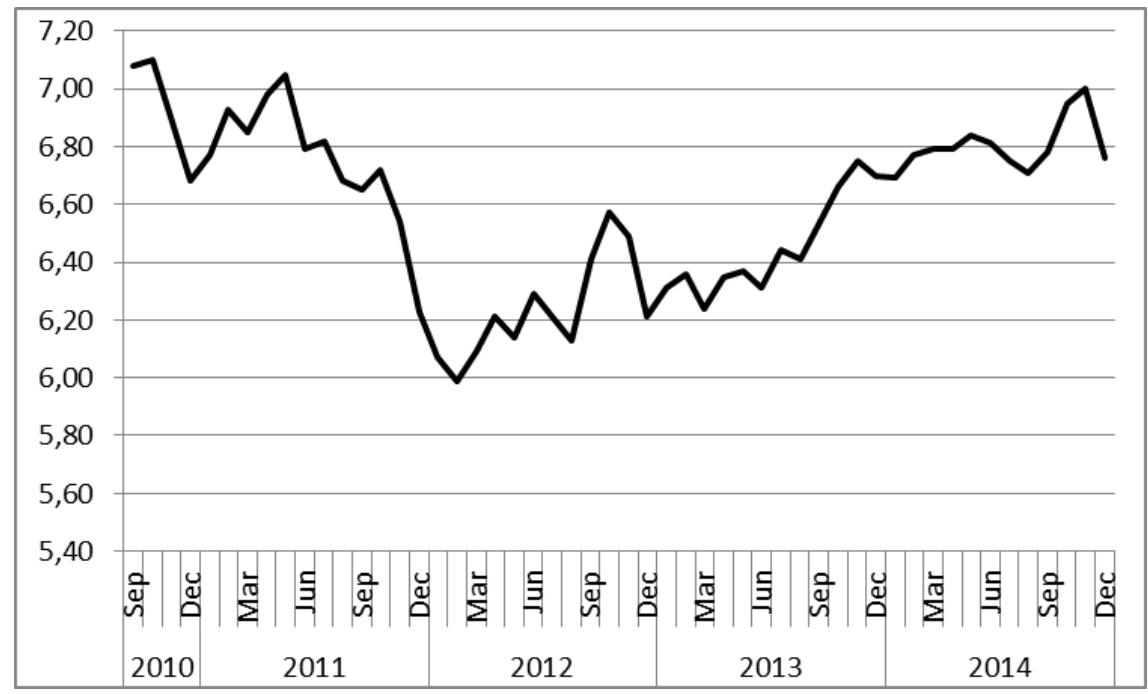

Source: NBS

Spread volatility during the analyzed period is mainly influenced by loan interest rate. It is especially significant after the intensification of global financial crisis, while the changes of deposit interest rates remained quite low. 


\section{Data and methodology}

Estimation analysis of transmission mechanism in Serbia is based on monthly data between the periods January 2007-December 2014. Variables used in study are:

- $\quad$ Real GDP, quarterly series are decomposed to monthly series using ECOTRIM software, using Boot, Feibes and Lisman (BFL) smoothing method - variable y

- consumer price index- variable $p$

- $\quad$ real effective exchange rate-variable reer1

- $\quad$ key interest rate-variable repo

- monetary aggregate m3-variable M3

- $\quad$ three month Euribor interest rate-variable euribor

- $\quad$ world oil price- variable oil

In empirical analysis of transmission mechanism, the interest and exchange rate channel will be analyzed. Beside the analysis of interest rate and exchange rate shock, the influence of expansionary monetary policy on real variables using monetary aggregate $\mathrm{M} 3$ is also studied. Two specification of model are defined, with goal to better identify proper model.

First model, Model 1, contains endogenous and exogenous variables presented with following equation.

$$
Y_{t}=A(L) Y_{t-1}+B(L) X_{t}+\mu_{t}
$$

Where $Y_{t}$ is vector endogenous variables, while $X_{t}$ is vector of exogenous variables. In first specification endogenous vector contains real GDP, consumer price index, key interest rate, monetary aggregate M3 and real effective exchange rate. The order of monetary aggregate and exchange rate variables are determined by assumption that exchange rate is momently affected by different shocks, while money supply is solely affected by monetary variables. Supporting assumption is that in short term, shocks on real variables of monetary policy doesn't have simultaneous effect on real GDP and prices, due to slow reaction of real sector on monetary and exchange rate shocks.

$Y_{t}=\left[y_{t}, p_{t}\right.$, repo $_{t}, M 3_{t}$, reer $\left._{t}\right]$

Vector of exogenous variables contains three month Euribor interest rate and oil price. 


$$
X_{t}=\left[\text { euribor }_{t}, \text { oil }_{t}\right]
$$

The important feature of banking sector in Serbia is that significant number of banks is financed from abroad, mostly on European financial market. Domestic deposit base is insufficient for rising loan demand. Interest rate on euro currency is supposed to prominently influence the formation of loans interest rates, and therefore aggregate demand. Due to this, in the second model, three month interest rate can be observed as endogenous variable. New specification, Model 2, is presented by following equation:

$$
Y_{t}=\left[y_{t}, p_{t}, \text { repo }_{t}, \text { euribor }_{t}, M 3_{t}, \text { reer }_{t}\right]
$$

While the vector of exogenous variables contains only oil price

Determination of variables order implies that some of the variable rather follows than react in relation with other variables. If order is not adequate, the sensitivity of results can be observed by changing the order and recalculating impulse response and variance decomposition. It is important to emphasize that if the residuals are more correlated, it is more important to properly define the order. (Lutkepohl, 1991).

In estimation of relationship between output, prices and monetary variables, stationarity of series is important. As in most models of monetary transmission, there will be presented explicit analysis of long term relationship in economy. Conducting the analysis in levels, it is allowed implicit cointegrating analysis of series. Implying the restrictions of cointegration on VAR levels, can elevate the estimation efficiency. However, taking into consideration short term series can drive to certain abnormalities. As transmission of monetary policy is short term phenomenon, in some studies is used unrestricted VAR in levels in order to estimate impulse response and variance decomposition in short and long term (Favero, 1999). Moreover, in order to estimate shock on variables, it needs to consider all developments in series. By differentiating series in order to gain stationarity, the changes in series that can be crucial for shock analysis are smoothened. Therefore, in this paper we will use variables in levels despite non stationary character.

\section{Results and discussion}

In order to estimate VAR model, diagnostic test are implied. According to Akaike and Schwarz criteria, chosen number of lags is 3 . Model does not suffer from serial correlation and heteroscedasticity, and satisfies the 
normality condition. Additionally, model satisfies stability condition, since all unit roots lays in unit root circle.

Figure 2. Inverse roots

Inverse Roots of AR Characteristic Polynomial

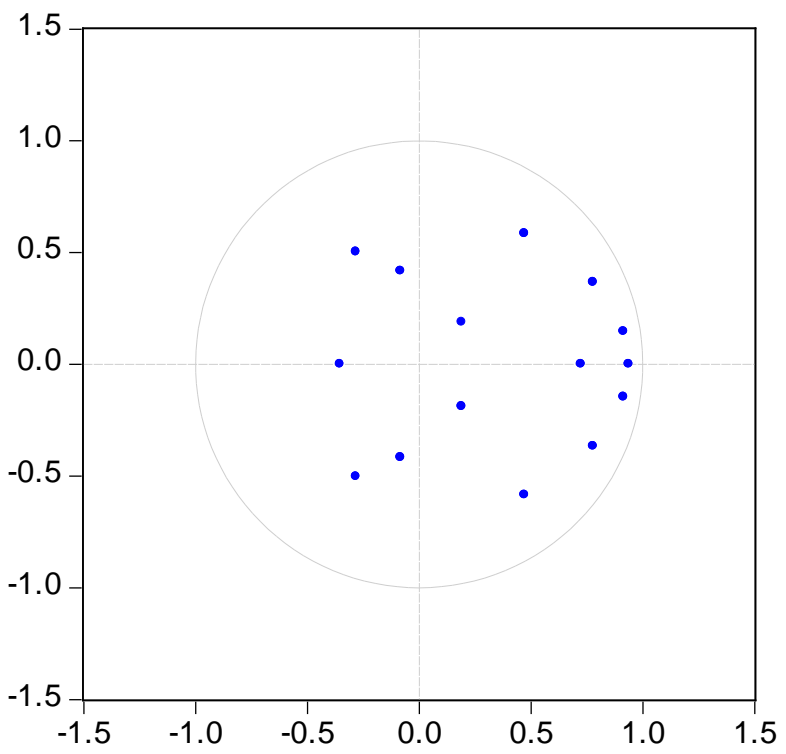

Source: Authors

Granger causality test implies correlation between present variable value and past values other variables, but not variables interdependence. This test does not show the sign of correlation. Granger test reports causality of exchange rate to inflation, while other variables don't cause inflation changes. Monetary aggregate displays causal relationship with GDP (Table 3).

Impulse response function exhibits all reaction of endogenous variable on unit standard deviation shock. In case of Serbia, unexpected increase of M3 has positive effect on GDP, which is statistically significant between $5^{\text {th }}$ and $8^{\text {th }}$ month. The unexpected shock of other variables on GDP doesn't have statistical significance. Real effective exchange rate has statistically significant impact on inflation. Unexpected appreciation shock cause inflation decrease between $5^{\text {th }}$ and $12^{\text {th }}$ month, afterwards shock diminishes. In addition, shock of monetary aggregate causes increase in inflation in period from $9^{\text {th }}$ to $15^{\text {th }}$ 
Bungin S. et al.: Estimation of Transmission Mechanism of Monetary Policy in Serbia

month. Also, there is statistical significant reaction of inflation on sudden increase of key interest rate. Inflation decreases in between $11^{\text {th }}$ and $17^{\text {th }}$ month.

Table 3. Granger Causality Test

VAR Granger Causality/Block Exogeneity Wald Tests

\begin{tabular}{cccc}
\hline \hline Dependent variable: $Y$ & & & \\
\hline \hline Excluded & Chi-sq & df & Prob. \\
\hline \hline P & 5.309623 & 3 & 0.1505 \\
REER1 & 1.451769 & 3 & 0.6934 \\
M3 & $\mathbf{1 0 . 9 1 1 1 7}$ & $\mathbf{3}$ & $\mathbf{0 . 0 1 2 2}$ \\
REPO & 4.438264 & 3 & 0.2179 \\
\hline \hline All & 20.09132 & 12 & 0.0654 \\
\hline \hline Dependent variable: P & & & \\
\hline \hline Excluded & Chi-sq & df & Prob. \\
\hline \hline Y & 2.640234 & 3 & 0.4505 \\
REER1 & $\mathbf{1 2 . 4 9 0 0 6}$ & $\mathbf{3}$ & $\mathbf{0 . 0 0 5 9}$ \\
M3 & 3.388128 & 3 & 0.3356 \\
REPO & 0.669819 & 3 & 0.8803 \\
\hline \hline All & 22.93139 & 12 & 0.0283 \\
\hline \hline
\end{tabular}

Source: Author

Variance decomposition is an alternative method impulse response function, where the effects of shock on depended variables are estimated. The technique determines how much the forecast error variance for each variable is explained by innovation in system for each independent variable in certain time horizons. In this model, the results of variance decomposition report that in two year period, monetary aggregate accounts for $7.6 \%$, while exchange rate accounts for $11 \%$ GDP fluctuations. Exchange rate has strongest prediction power for inflation. In one year period, exchange rate accounts for inflation fluctuations in $22 \%$. In two years period M3 accounts for $14 \%$, and key interest rate $18 \%$ inflation fluctuations. 
Bungin S. et al.: Estimation of Transmission Mechanism of Monetary Policy in Serbia

Figure 3. Impulse Response

Response to Cholesky One S.D. Innovations \pm 2 S.E.
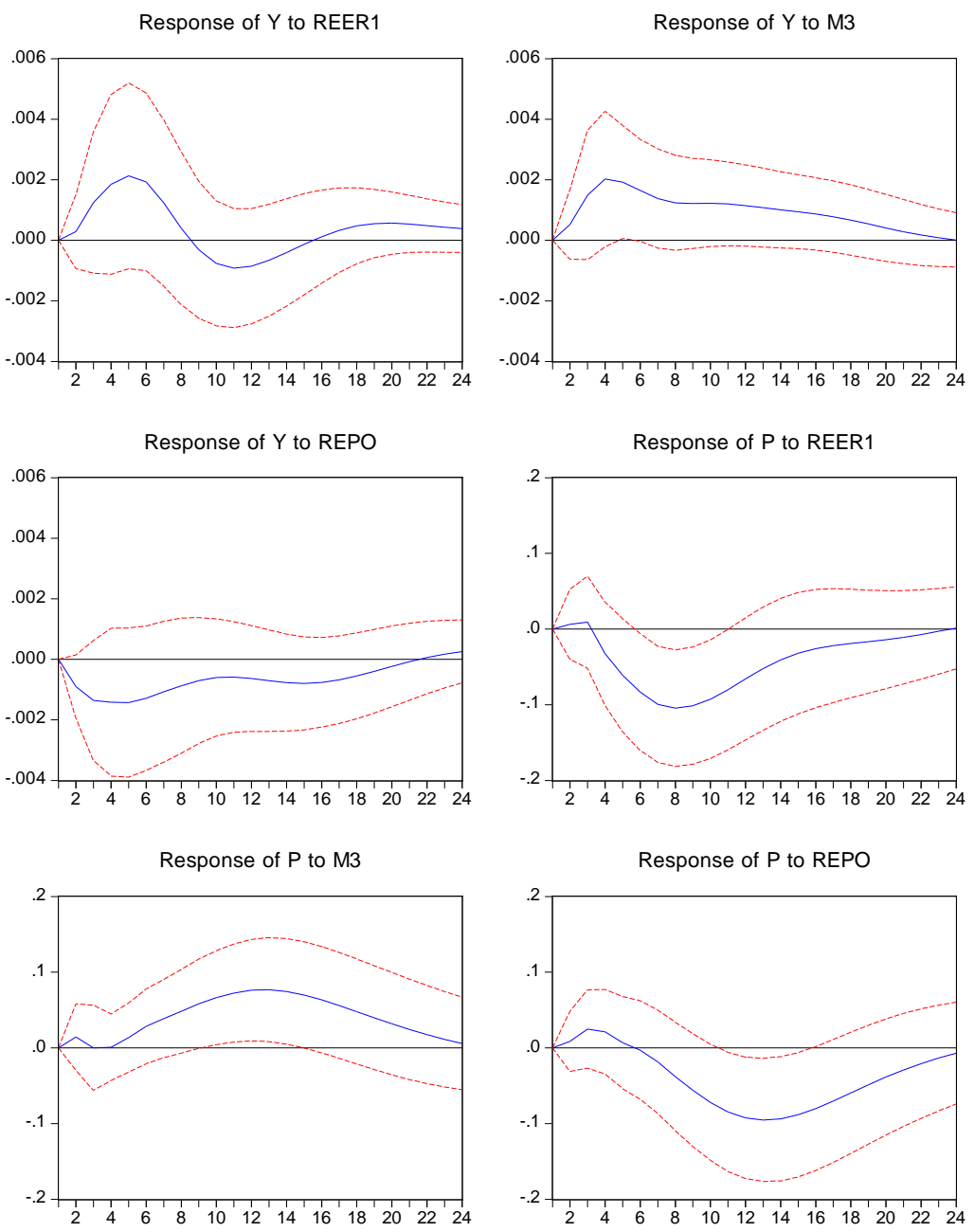

Source: Author

In Model 2, three month Euribor is chosen as endogenous variable. Number of lags is 2 , since the model satisfies stability condition. Data reports that there is causal relationship between GDP and Euribor, but also between inflation and exchange rate. 
Bungin S. et al.: Estimation of Transmission Mechanism of Monetary Policy in Serbia

Table 4. Granger Causality Test

VAR Granger Causality/Block Exogeneity Wald Tests

Date: 10/09/15 Time: 22:14

Sample: 2007M01 2014M12

Included observations: 94

\begin{tabular}{cccl}
\hline \hline Dependent variable: $Y$ & & \\
\hline \hline Excluded & Chi-sq & df & Prob. \\
\hline \hline P & 3.511252 & 2 & 0.1728 \\
REER1 & 0.471557 & 2 & 0.7900 \\
EURIBOR & $\mathbf{1 1 . 4 4 8 6 0}$ & $\mathbf{2}$ & $\mathbf{0 . 0 0 3 3}$ \\
M3 & 17.27803 & 2 & 0.0002 \\
REPO & 1.110345 & 2 & 0.5740 \\
\hline \hline All & 20.64280 & 10 & 0.0237 \\
\hline \hline Dependent variable: P & & \\
\hline \hline Excluded & Chi-sq & df & Prob. \\
\hline \hline Y & 0.887370 & 2 & 0.6417 \\
REER1 & $\mathbf{1 5 . 2 2 5 3 5}$ & $\mathbf{2}$ & $\mathbf{0 . 0 0 0 5}$ \\
EURIBOR & 5.279950 & 2 & 0.0714 \\
M3 & 2.424970 & 2 & 0.2975 \\
REPO & 0.076079 & 2 & 0.9627 \\
\hline \hline
\end{tabular}

Source: Author

Introducing Euribor, results slightly change in comparison to Model 1. Foreign interest rate shock causes an increase of GDP and inflation. In this case "price puzzle" can be taken into consideration, when producers load cost of financing on final products. There is also a bit of the puzzle when unexpected change of Euribor causes increase of GDP, that can't be explained by economic intuition. Other variable reports same impact as in Model 1.

Having Euribor as endogenous variable, smooths the impact of other variables in variance decomposition. Three month Euribor and monetary aggregate explains the greatest proportion of GDP fluctuations. In one year period, exchange rate still has strong predicting power. In two years period, exchange rate explains 19\%, while Euribor explains 12\% inflation fluctuations. The results clearly indicate that three month Euribor can be considered as endogenous variable and has significant influence on real variables. 
Bungin S. et al.: Estimation of Transmission Mechanism of Monetary Policy in Serbia

Figure 4. Impulse response

Response to Cholesky One S.D. Innovations \pm 2 S.E

Response of $\mathrm{P}$ to REER1

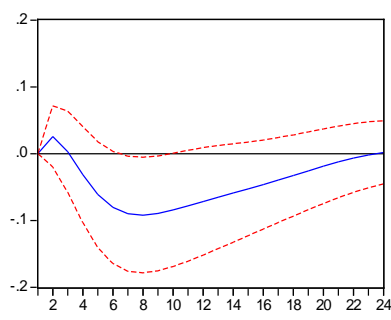

Response of P to REPO

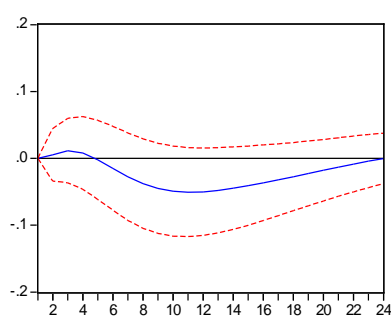

Response of $\mathrm{Y}$ to $\mathrm{M} 3$

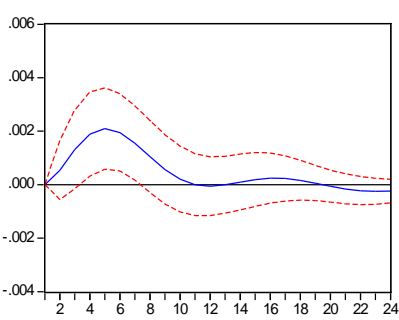

Response of $\mathrm{P}$ to EURIBOR

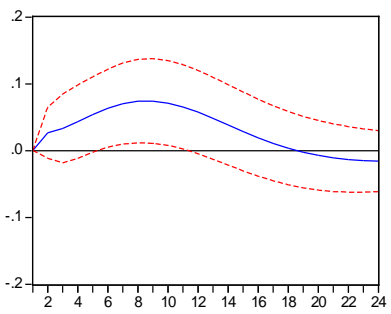

Response of $Y$ to REER 1

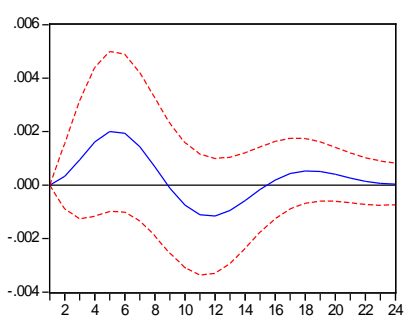

Response of $\mathrm{Y}$ to REPO

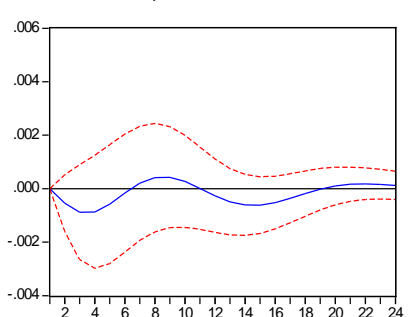

Response of $\mathrm{P}$ to $\mathrm{M} 3$

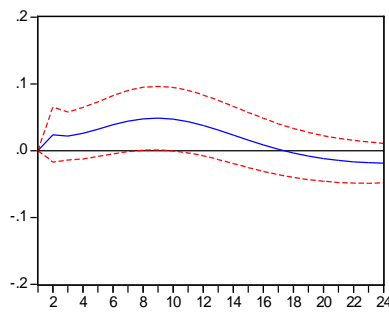

Response of $\mathrm{Y}$ to EURIBOR

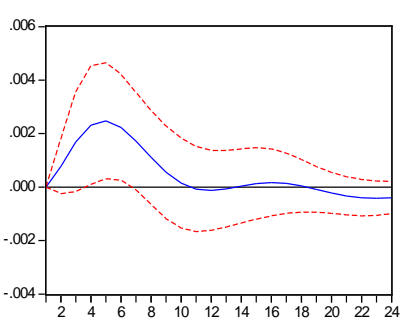

Source: Author

\section{Conclusion}

High level of economy eurisation presents key element for such exchange rate significance. In these circumstances, monetary authorities have not so many options in influencing inflation. Narrow set of financial instruments denominated in dinars complicates implementation of key interest rate as a main instrument of monetary policy in inflation targeting regime. Lack of 
longer term instruments denominated in dinars prevents managing inflationary expectation based on interest rate movements. Accordingly, for successful implementation of inflation targeting in Serbia, it is necessary to regulate and improve conditions that constrain monetary authorities. Having in mind empirical results, which indicate strong influence of exchange rate on inflation, managing inflationary expectations basically depends on exchange rate movements. The experience of countries that successfully passed transition process shows that exchange rate volatility brings stronger exchange rate channel. Therefore, managing exchange rate fluctuations seems as necessity, when NBS indirectly influences foreign exchange market by changing interest rate, or directly by using foreign reserves. Although quite unexpected, there are some signs of key interest rate influence on inflation, but the effect is smaller and shorter comparing to exchange rate. There is also significant impact of monetary aggregate M3 on both GDP and inflation, which indicate a correlation between money supply and real variables.

Based on theoretical assumption and empirical evidence, there can be identified limitation for effective implementation of monetary strategy. Although Serbia is quite unfavorable environment for inflation targeting, it is the most optimal solution from this point of view. Targeting exchange rate proved to be time limited, while monetary aggregate targeting is questionable due to unreliable relations between money supply end real economy. In order to improve performance of inflation targeting, level of eurisation needs to be lowered. Dinarisation strategy has not considerably improved situation by this moment and it's even questionable whether it is still in operation. Moreover, the structure of banking system is not an effective provider of monetary policy signals. Therefore, in this surrounding it is not reasonable to expect better performance of monetary policy influencing financial market and real economy by key interest rate.

In Serbia, high and volatile inflation has been mainly caused by lack of fiscal discipline. Due to recent reduction of budget deficit and more responsible fiscal policy, more efficient monetary policy can also be reachable.

\section{References}

Aleksić, M., Đurđević, L.J., Palić, M., \& Tasić, N. (2008). Interest Rate Transmission in a Dollarized Economy: The Case of Serbia. National Bank of Serbia. Retrieved from http://www.nbs.rs/internet/english/90/90 0/

Babecká-Kucharèuková, O. (2009). Transmission of Exchange Rate Shocks into Domestic Inflation: The Case of the Czech Republic. Czech Journal of Economics and Finance (Finance a uver), 59(2), 137-152. Charles University Prague, Faculty of Social Sciences, June. 
Bungin, S., Filipović, S., \& Matović, D. (2012). Carry Trade as a Speculative Investment Strategy in Serbia. Industrija, 40(4), Oct-Dec.

Case of the Czech Republic," Czech Journal of Economics and Finance (Finance a uver), Charles University Prague, Faculty of Social Sciences, vol. 59(2), pages 137-152, June.

Chailloux, A., Ohnsorge, F., \& Vavra, D. (2010). Euroisation in Serbia. Retrieved from http://www.ebrd.com/downloads/research/economics/workingpapers/wp0120.pdf

Darvas, Z. (2013). Monetary transmission in three central European economies: Evidence from time-varying coefficient vector autoregressions. Empirica, 40(2), 363-390. Springer, May. doi:10.1007/s10663-012-9197-4

Dragutinović, D. (2008). Moć i nemoć monetarne politike uuspostavljanju ravnoteže između platnobilansnih ciljeva $i$ ciljeva inflacije. National Bank of Serbia. Retrieved

from http://www.nbs.rs/export/sites/default/internet/latinica/90/90 0/2008_12 DD.pdf

Economy: the Case of Serbia. in: Working Paper, National Bank of Serbia, (15), http://www.nbs.rs/internet/english/90/90_0/

Favero, C.A. (1999). Applied Macroeconometrics. Oxford: University Press. Retrieved from http://www.bseu.by/russian/faculty5/stat/docs/4/FaveroApplied\%20Macroeconometrics.pdf

Franta, M., Horvath, R., \& Rusnak, M. (2014). Evaluating the Changes of Monetary Transmission Mechanism in the Czech Republic. Empirical Economics, 46(3), 827-842.

-International Monetary Fund. (2010). Republic of Serbia: Financial Sector Assessment Program Update- Technical Note on Systemic Liquidity Management. Retrieved from https: //www.Imf.Org/external/pubs/ft/scr/2010/cr10153.pdf

Josifidis, K., Allegret, J., \& Beker-Pucar, E. (2009). Monetary and exchange rate regimes changes: The Cases of Poland, Czech Republic, Slovakia and Republic of Serbia. Panoeconomicus, 56(2), 199-226.

Kujundzic, S., \& Otasevic, D. (2012). The Bank Lending Channel in an Euroised Economy: The Case of Serbia. National Bank of Serbia. Retrieved from http://www.nbs.rs/export/sites/default/internet/english/90/90 0/2012 24 SK DO e.pdf

Łyziak, T., Kapuściński, M., Stanislawska, E., Przystupa, J., Wrobel, E., \& Sznajderska, A. (2014). Monetary policy transmission mechanism in Poland What do we know in 2013. National Bank of Poland, Economic Institute. Retrieved from http://www.nbp.pl/publikacje/materialy_i_studia/180_en.pdf

Lutkepohl, H. (1991). Introduction to Multiple Time Series Analysis. Berlin: SpringerVerlag.

Lutkepohl, H. . Reports on Banking Sector. Retrieved from http://www.nbs.rs/internet/latinica/55/55 4/index.html

Miljković M, F. . Tržišna koncentracija u bankarskom sektoru - primer Srbije. Industrija, 41, 7-25.

Tasić, N. (2008). Pass-Through of Exchange Rates to Prices in Serbia: 2001-2007. Retrieved from http://www.nbs.rs/internet/english/90/90_0/

Vilaret, S., \& Palić, M. (2006). Exchange rate pass-through effect on prices in Serbia. Retrieved from http://www.nbs.rs/internet/english/90/90_0/ 